\title{
ATRIAL NATRIURETIC FACTOR IN BILHARZIAL HEPATIC FIBROSIS AND POSTHEPATITIC CIRRHOSIS
}

'By

\author{
Rizk, H.; Badr, A.; Sarhan, M.*; El-Rakhawy, M.**; \\ Abo Hashem, E. ${ }^{* * *}$ and Shaat, $M$.
}

\author{
From \\ General Medicine, Physiology*, Radiology** and
}

Clinical Pathology Departments, Mansoura Faculty of Medicine, Mansoura University,

Received for Puplication : 22/2/1992

\section{ABSTRACT}

Elevated levels of plasma atrial natriuretic factor (ANF) were found in cirrhotic patients. Some investigators reported basal levels, while other reported low levels of ANF.

This lead us to investigate the effect of bilaharzial periportal fibrosis (BPD) and bilharzial liver cirrhosis and posthepatitic cirrhosis on plasma ANF.

27 patients were selected and divided into three groups. The first group comprized nine patients of bilharzial periportal fibrosis. The second group comprized 9 patients of mixed cirrhosis without ascites. The third group comprized 9 patients of mixed cirrhosis and ascites.

ANF was measured by radioimmunoassay. Abdominal and cardiac ultrasonography was used for measurement of liver size and echogenicity together with diameter of portal vein, splenic view and cardiac chambers.

The results showed that ANF was reduced in all group of patient except those developing ascites, they showed levels slightly more than the control group.

\section{INTRODUCTION AND AIM OF THE WORK}

One of the most exciting recent major advance in physiology and MANSOURA MEDICAL JOURNAL 
medicine was made when natriuretic granules were discovered in the atria of the heart (Mills, 1984).

Elevated levels of plasma atrial natriuretic factor (ANF) were found in cirrhotic patients (Fernandez-Grus et al., 1985), some investigators such as Burghardt et al., 1988a and Salerno et al., 1990) found basal plasma level sirtlialr to control subjects in cirrhotic patients without ascites. Only one group of workers showed slightly lower ANF in ascitic patients (BanKovsky et al., 1986).

The present work is a trial to study the possible changes in plsma ANF in patients with hepatosplenic bilharziasis with and without liver cirrhosis, with and without ascites, and the potential role of ANF in the pathogenesis of impaired sodium homeostasis in such patients.

\section{Materials:}

The present study comprised 27 patients of both sexes with age ranging from 16-55 years and 9 healthy subjects of matched age and sex as conVol. 22, No. 1 \& 2 Jan. \& April 1992 trol group. The patients were divided into three groups :

Group I: 9 patients with pure bilharzial periportal fibrosis (BPF).

Group II: 9 patients with mixed BPF and post hepatitic cirrhosis without ascites.

Group III: 9 patients with mixed BPF. and post hepatitic cirrhosis with ascites.

All patients were subjected to thorough history taking and clinical examination. Patients with present and past history of cardiac and renal diseases were excluded as well as hypertensive patients and females on pills. Both patients and control were on normal sodium diet. Drug therapy, especially diuretics, were stopped at least one week before blood sampling.

The diagnosis of bilharzial aetiology is based upon history of bilharziasis and its treatment, urine and stool analysis for bilharzial ova, irnmunodi- 
agnosis of schistosomiasis and liver biopsy. The diagnosis of post hepatitic cirrhosis is based upon the clinical hictory of hepatitis, elevated serum bilirubin and transominases, positive markers of B\&C viruses and by liver biopsy.

\section{Methods:}

a) Analytic methods:

1- Plasma immunoreactive (PIR) atrial natriuretic factor using radioimmunoassay (RIA) kits provided by Peninsula laboratories Inc.

2- Serum creatinine estimation (Langley \& Evans, 1963).

3- Serum and urinary sodium estimation using KNA radiometers.

4- Serum albumin by biodynamic unitest system (Doumas \& Biggs, 1972).

5- Serum bilirubin by colorimetric method described by Ferro \& Ham, (1963).
6- Serum transaminases by the method described by Ritman \& Frankel, 1957.

7- Vinal markers:

8- Serological diaynosis for schistosoma mansoni.

b) Liver biopsy.

c) Abdominal ultrasonography for;

1) Size \& Echogenicity of the liver and spleen.

2) Portal vein diameter (PVD).

3) Splenic vein diameter (SVD).

d) Echocardiography for;

I) Left atrial diameter ( $L A D)$ range $2.3-4.4 \mathrm{~cm}$.

2) Right ventricualr dimension (RVD range $0.7-2.3 \mathrm{~cm}$. The measurements are according to Feigenbaum, 1986.

E) Statistical analysis using;

I) Unpaired T-Test. 
2) One way analysis of variance using scheffe method.

\section{RESULTS}

Are tabulated in tables (1-4).

\section{DISCUSSION}

The low level of ANF found in our patients in groups I \& II can be explained by insufficient stimulation for ANF release. In these two groups of patients there is significant decrease in serum albumin which leads to decreased circulating blcod volume.

Another possible explanation for the reduced level of ANF is the increased capacity of the circulation. These patients suffer from huge portosystemic shunting and huge collateral circulation as evidenced by the significant increase in portal vein and splenic vein diameter, serving to sequesterate blood away from the heart.

The proposal that the decreased circulating blood volume and/or increased capacity of the circulation as a cause for reduced ANF level, is faced by another contradictory findiny, that is to say, the significant increase in left atrial diameter. According to Mebazaa and Payen, 1990, ANF must be increased rather than to be decreased, these workers suggested that atrial distension is the main stimulus for ANF rlease.

The increased left atrial diameter observed in this work is in agreement with that of Rector \& Hossack, 1988 and Rector et al. 1990. They found that patients with alcoholic liver cirrhosis have significant larger left atrial diameter in cases with and without ascites.

The dissociation between plasma ANF and left atrial diameter has been reported by several authors such as Au et al. 19gO; Berglund et al., 1990 and Nakamura et al., 1990. Only Matsubara et al., 1987 revealed that elevation of atrial (Principally left atrium) pressure stimulates ANF secretion in man.

With progression of cirrhosis and development of ascites ANF again begins to increase significantly in 
patients of group III as regard non ascitic patients of group I and II. This is not astonishing because with progression of liver cirrhosis there is more it duction in serum albumin, accordingly there will be more decrease in circulating blood volume. The body senses the hypovolemia as stress which results in persistant stimulation of stressfull mechanisms such as sympathetic stimulation, activation of renin angiotensin aldosterone (RAA) system, $\mathrm{ADH}$ and cortisol.

These neurohumoral and hormonal factors are supposed by Ballerman et al. 1986 and Gardner et al., 1988 to have direct stimulatory effect at the level of myocytes to incraese ANF synthesis. Klemin et al. 1988 mentioned that angiotensin II (AII) increase ANF level especially when blood volume is low. Ballerman suggested that ANF acts as a counter mechanism against stress. It is released by the stressfull hormones themselves to check and pervent the overshooting of these stressfull substances.
Laragh et al., 1986 mentioned 4 different ways by which ANF counteracts or opposes RAA system -1-by reducing renin secretion -2- by relaxing angiotensisn contracted vessels 3- by blocking angitensin induced aldosterone synthesis and -4- by its natriuresis opposing aldosterone induced sodium retension. So in volume contracted disorders the neurohumoral and hormonal factors, not the atrial distension, can be the main stimuli for ANF release.

In cirrhotic patients of the group III, there is marked decrease in urinary sodium excretion inspite of the marked enhancement of ANF level which is supposed to act in the way of increasiny urinary sodium excretion. Schowalter et al., 1988 reported attenuated natriuresis to ANF in the presence of intra-renally infused angiotensin II, also MC Murray and Struthers, 1988 showed that the renal effects of ANF were reduced in the presence of simultaneously elevated level of angiotensin II. 
These previous observations could marked enhancement of ANF level, explain the blunted natriuresis in cir- especially in patients having high rerhotic ascitic patients inspite of the nin angiotensin aldosterone activity.

Table (!) : Comparison between different groups of patients (Gp. I, II, III) and control group according to biochemical data.

\begin{tabular}{|c|c|c|c|c|c|}
\hline \multirow[t]{2}{*}{ Group } & & \multicolumn{4}{|c|}{ Variable } \\
\hline & & ANF & S. $\mathrm{Na}$ & Una & S. alb. \\
\hline \multirow[t]{2}{*}{ Control } & Mean & 232.4 & 136.7 & 151.6 & 4.3 \\
\hline & $S D_{ \pm}$ & 43.6 & 3.16 & 26.8 & 0.27 \\
\hline \multirow[t]{3}{*}{ Gp. 1} & Mean & 173.3 & 136.7 & 145.9 & 3.77 \\
\hline & $S D_{ \pm}$ & 25.6 & 5.94 & 28.8 & 0.56 \\
\hline & $P$ & $<0.001$ & 0 & $>0.05$ & $<0.05$ \\
\hline \multirow[t]{3}{*}{ GP. II } & Mean & 176.6 & 131.2 & 114.6 & 3.4 \\
\hline & $S D_{ \pm}$ & 25.7 & 3.8 & 26.7 & 0.35 \\
\hline & $P$ & $<0.001$ & $>0.05$ & $<0.001$ & $<0.001$ \\
\hline \multirow[t]{3}{*}{ Gp. III } & Mean & 273.4 & 122.2 & 50.18 & 2.9 \\
\hline & $S D_{ \pm}$ & 87.6 & 4.17 & 15.9 & 0.27 \\
\hline & $P$ & $>0.05$ & $<0.01$ & $<0.001$ & $<0.001$ \\
\hline
\end{tabular}

ANS $=$ Atrial natriuretic factor $\mathrm{pg} / \mathrm{ml}$.

$\mathrm{S} . \mathrm{Na}=$ Serum sodium concentration $\mathrm{meg} / \mathrm{L}$.

$\mathrm{UNa}=$ Urinary sodium excretion meq/day.

S. $a l b=$ Serum albumin $\mathrm{gm} / \mathrm{dl}$.

Vol. 22, No. 1 \& 2 Jan. \& April 1992 


$$
\text { Rizk, H.; et al... }
$$

Table (2) : Comparison between group I, II, III of patients acccrding to biochemical data by biochemical data by one way analysis of variance.

\begin{tabular}{|c|c|c|c|c|c|c|}
\hline & & Group & & & & \\
\hline Variable & & GPI & $G P \|$ & GP III & $P$ & \\
\hline \multirow[t]{2}{*}{ ANF } & Mean & 173.2 & 176.6 & 273.4 & $<0.001$ & I, III \\
\hline & $S D_{ \pm}$ & 35.6 & 25.7 & 87.6 & & II, III \\
\hline \multirow[t]{2}{*}{$\mathrm{S}>\mathrm{Na}$} & Mean & 136.7 & 131.2 & 122.2 & $<0.003$ & I, ill \\
\hline & $S D_{ \pm}$ & 5.9 & 3.8 & 4.17 & & \\
\hline \multirow[t]{2}{*}{ U. $\mathrm{Na}$} & Mean & 145.9 & 114.6 & 50.18 & $<0.001$ & I,II,III \\
\hline & $\mathrm{SD}_{ \pm}$ & 28.3 & 26.7 & 15.9 & & \\
\hline \multirow[t]{2}{*}{ S. alb } & Mean & 3.77 & 3.4 & 2.9 & $<0.008$ & I,III \\
\hline & $\mathrm{SD}_{ \pm}$ & 0.55 & 0.35 & 0.27 & & \\
\hline
\end{tabular}

I, III = The compairson made between groups I, IIII is significant.

II, III = The compairson made between groups II, IIII is significant.

I, II, III = The compairson made interbetween different grcups is significant. 
Table (3) : Comparison between groups (I, II, III) of patients and control group according to abdominal U/S \& Echocardiographic parameters.

\begin{tabular}{|c|c|c|c|c|c|}
\hline \multirow[t]{2}{*}{ Group } & & \multicolumn{4}{|c|}{ Variable } \\
\hline & & PVD & SVD & LAD & RVD \\
\hline \multirow[t]{2}{*}{ Control } & Mean & 0.94 & 0.74 & 3.12 & 1.8 \\
\hline & $S D_{ \pm}$ & 0.1 & 0.12 & 0.19 & 0.12 \\
\hline \multirow[t]{3}{*}{ Gp. 1} & Mean & 1.87 & 1.7 & 3.7 & 1.77 \\
\hline & $\mathrm{SD}_{ \pm}$ & 0.87 & 0.33 & 0.41 & 0.16 \\
\hline & $P$ & $<0.001$ & $<0.001$ & $<0.01$ & $>0.05$ \\
\hline \multirow[t]{3}{*}{ GP. ॥ } & Mean & 1.96 & 1.83 & 3.71 & 1.88 \\
\hline & $S D_{ \pm}$ & 0.19 & 0.39 & 0.31 & 0.35 \\
\hline & $P$ & $<0.001$ & $<0.001$ & $<0.01$ & $>0.05$ \\
\hline \multirow[t]{3}{*}{ Gp. III } & Mean & 1.63 & 1.26 & 3.17 & 1.82 \\
\hline & $\mathrm{SO}_{ \pm}$ & 0.43 & 0.22 & 0.5 & 0.12 \\
\hline & $P$ & $<0.001$ & $<0.001$ & $>0.05$ & $>0.05$ \\
\hline
\end{tabular}

PVD $=$ Portal vein diameter in $\mathrm{cm}$.

SVD $=$ Splenic vein diameter in $\mathrm{cm}$.

$L A D=$ Left atrial diameter in $\mathrm{cm}$.

$\mathrm{RVD}=$ Right ventricualr diamension in $\mathrm{cm}$.

$\mathrm{U} / \mathrm{S}=$ Ultrasonography.

Vol. 22, No. 1 \& 2 Jan. \& April 1992 
Table (4) : Comparison between group I, II, III of patients according to abdominal U/S and Echocardiographic parameters by one way analysis of variance.

\begin{tabular}{|c|c|c|c|c|c|c|}
\hline & & Group & & & & \\
\hline Variable & & GPI & GP ॥ & GP III & $P$ & \\
\hline \multirow[t]{2}{*}{ PVD } & Mean & 1.87 & 1.96 & 1.63 & $<0.1$ & \\
\hline & $\mathrm{SD}_{ \pm}$ & 0.27 & 0.19 & 0.43 & & \\
\hline \multirow[t]{2}{*}{ SVD } & Mean & 1.7 & 1.83 & 1.26 & $<0.002$ & I, III \\
\hline & $\mathrm{SD}_{ \pm}$ & 0.33 & 0.39 & 0.22 & & II, III \\
\hline \multirow[t]{2}{*}{ LAD } & Mean & 3.7 & 3.71 & 3.17 & $<0.01$ & I, III \\
\hline & $S D_{ \pm}$ & 0.41 & 0.31 & 0.5 & & II,III \\
\hline \multirow[t]{2}{*}{ RVD } & Mean & 1.77 & 1.88 & 1.82 & $<0.06$ & \\
\hline & $S D_{ \pm}$ & 0.16 & 0.35 & 0.12 & & \\
\hline
\end{tabular}

I, III = The compairson made between groups I, IIII is significant.

II, III = The compairson made between groups II. IIII is significant. 


\section{REFERENCES}

* Aa, J.; Brown, J. E.; Lee, M. R. and Boon, N. A. : Effect of cardiac tamponade on ANP concentrations. Clin. Sci., 7g: 377, 1990.

* Ballermann, B. J.; Bloch, K. D.; Seidman, J. G. and Brenner, B. M.: ANP transcription. J. Clin. Invest., 78: 84rJ, 1986.

"Bankovsky, H.; Hartle, D. and Simon, D. : Decreased plasma ANF in cirrhotic ascitic patients. Hepatology, 6: 1213, 1986.

* Berglund, H.; Boukter, S.; Theodorsson, E.; Vallin, H. and Edhag, O.: Raised plasma concentrations of ANP are independent of left atrial dimension. Br. Heart. J., 64: 9 , 1990.

* Burghardt, W.; Muller, R.; Dieghl, $K$. $L$ and Werhze, H.: Interrelationship between atrial

Vol. 22, No. 1 \& 2 Jan. \& April 1992 natriuretic peptide and plasma renin aldosterone and catecholamines in hepatic cirrhosis. The effect of passive Leg. risiny, Z. Kardiol. 77 : (Suppl 2): 104, 1988. Br. Med. J., 289: 210, 1984.

* Doumas, S. and Biggs, H. : Standard methods of clinical chemistry. Academic Press, N. Y.; Vol. 7: P. 175, 1972.

${ }^{*}$ Feigenbaum, H.: Echocardiography, 4th ed., Lea and Feb iger, Philadelphia, 3: 127, 1986.

* Fernandez-Cruz, A.; Marco, J.; Caudrodo, L. M. and Caramelo, C.: Plasma level of atrial natriuretic peptide in cirrhotic patients. Lancet II: 1439, 1985.

* Ferro, P. and Ham, A. : A new colourimetric method for the determination of total serum bilirubin. Am. J. Clin. Pathl., 40: 209, 1963. 
* Gardner, D. G.; Gertz, B. J.; Deschepper, C. F. and Kim, D. Y.: Gene for rat ANP is regulated by glucocorticoids in vitro. J. Clin. Invest., 82: 1275, 1988.

* Klemm, S. A.; Gordon, R. D.; Tunny, T. J. and Hanslet, S. M.: ALtering angiotensin levels contributes to an understanding of ANP regulation in man. Clin. Exp. Pharmacol. Physiol. 15: 349, 1988.

* Langley, W. and Evans, M. : Deterrrlination of serum creatinine by the picric acid method. J. Biol. Chem. $115: 333$, 1963.

* Laragh, J. H. : The endocrine control of blood volume, bLood pressure and sodium balance. Atrial hormone and renin sustem interaction. J. Hypertens. 4, (Suppl. 1, 2): S143, 1986.
* Matsubara, H.; Nishikawa, M. and Umeda, Y. : The role of atrial pressure in secreting atrial natriuretic polypeptides. Am. Heart. J., $113: 1457,1987$.

* McMurray, J. and Struthers, A. D. : Effect of All and ANP alone and in combination on urinary water and electrlyte excretion in man. Clin. Sci., 74 (4): $419,1988$.

* Mebazaa, A. and Payen, D. : Atrial natriuretic factor. Ann. Anaesth. Reanius, $9: 153$, 1990.

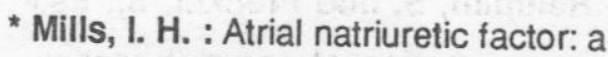
new hormone?

* Nakamura, M.; Arakawa, N.; Abe, Y.; Youshida, H. and Kato, H. : Relationship between plasma ANP concentration and atrial pressure in acute and chronic heart failure. Jpn. Heart. J., 31 : 425, 1990. 
* Rector, Jr. W. G. and Hossack, K. F.: Pathogenesis of sodium retention complication cirrhosis. Is there room for diminished "effective" arterial blood volume?. Gastroenterology, 95 : 16S8, 1988.

* Rector, Jr. W. G.; Adair, O.; Hassuck, K. F. and Rainguet, S. : Atrial volume in cirrhosis. Relationship to blood volume and plasma concentration of atrial natriuretic factor. Gastroenterology, $99: 766$, 1990.

* Reitman, S. and Frankel, S.: Estimation of serum transami- nases using the colorimetric method. Am. J. Clin. Path., $28:$ S6, 1957.

* Salerno, F.; BadalamentI, S.; Moser, P. and Incerti, P. : ANF in cirrhotic patients with tense ascites. Effect of large volume paracentesis. Gastroenterology, $98: 1063$, 1990.

* Schowalter, C. J.; Zimmerman, R. S. and Schwas, T. R. : Renal responses to ANF is mdulated by intrarenal ayiotensin II. Am. J. Physiol., 2S4 : R453, 1988. 